\title{
Mapuche cosmovision and territorial rights: An interdisciplinary approach to understand the conflict of Wallmapu, Chile
}

\author{
Ranjeeva Ranjan ${ }^{1,}{ }^{*}$, Alexis Castillo ${ }^{2} \&$ Karla Morales 3 \\ 1, "Asssitant Professor, Faculty of Educational Science, Universidad Católica del Maule, Talca, \\ Chile.Email: ranjan@ucm.cl \\ ${ }^{2}$ Researcher, Centro de investigación y estudios avanzados del Maule, Universidad Católica \\ del Maule, Talca, Chile. \\ ${ }^{3}$ Asssitant Professor, Centro de investigación y estudios avanzados del Maule, Universidad \\ Católica del Maule, Talca, Chile.
}

\begin{abstract}
The indigenous population of Latin America has been suffering from a sense of alienation since the arrival of Columbus in 1492 who referred to this land as "Nuevo Mundo". There is a long history of environmental exploitation in Chile which has severely strained the relationship amongst the Mapuche community, the State and private entities (hydroelectric and timber industry). Although this conflict seems to be economicproductive associated with land, wherein land attains a "tangible material good", in the Mapuche cosmovision, land (Mapu means land in Mapudungun, the language of Mapuche) acquires a connotation of "intangible material and immaterial good". There is a profound imperceptible connection between nature and Mapuche and their traditions and culture are strongly rooted in the land. The industrial expansion has promoted a series of negative externalities like habitat fragmentation, loss of native forest, biodiversity reduction, water availability, etc. These affect the "idiosyncrasy" of this community (Mapuche-Nature relationship) and loss of their land could represent an identity loss. The Chilean indigenous policy appears to be inadequate and fail to recognize the socio-cultural and territorial rights for all indigenous peoples, including Mapuche, given the multidimensionality of the land under the indigenous cosmovision. The sociopolitical measures imposed by the Chilean government until now to make their life "modern" boomeranged alienating them further from society. This paper proposes to look at the territorial rights of the Mapuche with an interdisciplinary approach and focuses on developing the conceptual framework of Mapuche cosmovision of land and territory. The study follows a brief analysis of the historical context of the territorial conflict between the Chilean State and the Mapuche people and how the implementation of national and international normative framework on indigenous rights has not been effective in resolving this territorial conflict. The study tries to synthesize and talks about integrating the Mapuche land cosmovision in the sociopolitical discourse and be considered while formulating any land policy involving Mapuche and other indigenous peoples inhabiting in Chile in future. The discussions and analysis have been carried out through a comprehensive literature review and integrate an interdisciplinary approach to look at this issue, both from the philosophical perspective and from the socio-political policy framework of government.
\end{abstract}

Keywords: Mapuche, Wallmapu, Territory, Social alienation, intangible material, Chile

\section{Introduction}

The indigenous population of Latin America has been suffering from a sense of alienation since the arrival of Columbus in 1492 who referred to this land as "Nuevo Mundo" (New World). Chile has

(C) AesthetixMS 2021. This Open Access article is published under a Creative Commons Attribution Non-Commercial 4.0 International License (http://creativecommons.org/licenses/by-nc/4.o/), which permits non-commercial re-use, distribution, and reproduction in any medium, provided the original work is properly cited. For citation use the DOI. For commercial re-use, please contact editor@rupkatha.com. 
many indigenous communities like Mapuche, Rapanui, Aymara, Chango, among others, whose total population is 2,185,792 (Instituto Nacional de Estadística INE ${ }^{1}$, 2017). Of these, the largest indigenous community is Mapuche with $77.4 \%$ of the population (Fig. 1).

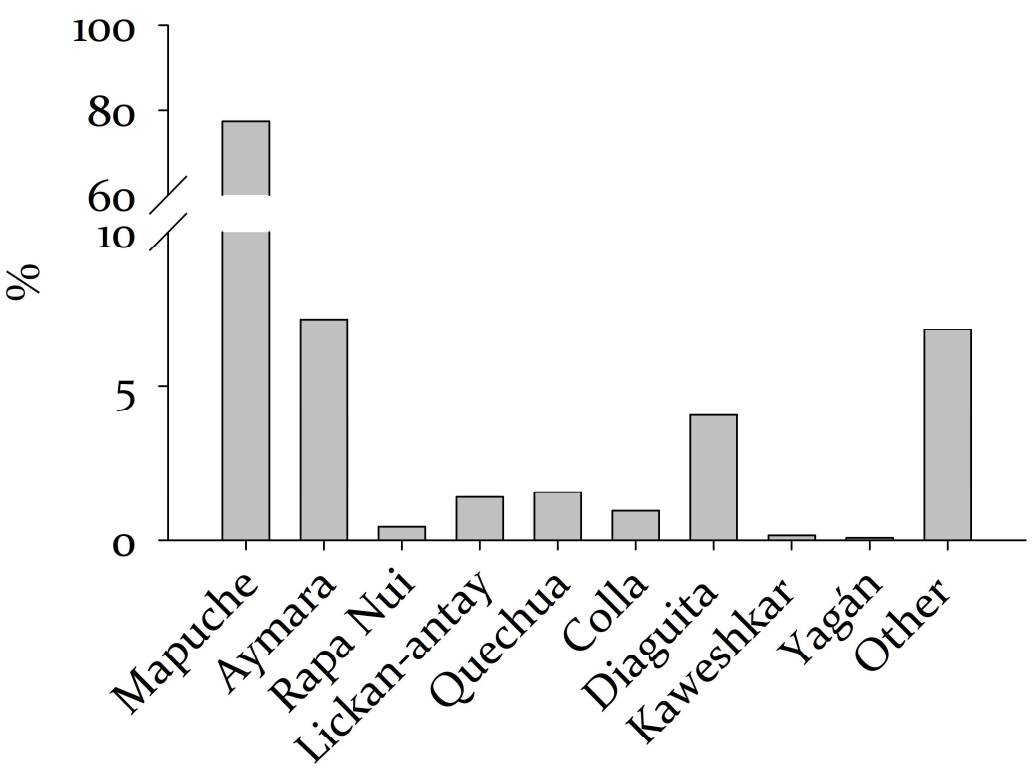

Figure 1: Distribution of the Chilean indigenous population (\%) according to the 2017 Census (INE, 2020)

This paper analyses the territorial conflict between Chile and the Mapuche people, which translated into a possible loss of identity and socio-cultural alienation of the Mapuche community living in the south of Chile. There is a long history of environmental exploitation in Chile which has severely strained the relationship between the Mapuche community, the State and the private entities (hydroelectric and timber industry). Although this conflict seems to be economicproductive associated with land, wherein land attains a "tangible material good", under the Mapuche cosmovision, land ("Mapu") acquires a connotation of "intangible material and immaterial good". As the name of the tribe itself suggests, there exists an imperceptible connection between nature and the Mapuche people. This situation of land manipulation exposes the fundamental problem that affects the Mapuche community, given that the land for them "is not only a portion of arable land for economic gains", but rather there is a deeper connection with the environment, wherein traditions and culture are strongly rooted in their land. The expansion of the hydroelectric and timber industry has promoted a series of negative externalities (like habitat fragmentation, loss of native forest, reduction of biodiversity and water availability, among others). These affect the "idiosyncrasy" of the Mapuche community (Mapuche-Nature relationship). More than the materialistic value, the loss of their land represents an identity loss.

In this context, Gray (2009) argues that territorial rights involve looking at the relationship between peoples and their environment through four interrelated terms: territory, land, earth and landscape. The concept of territory and land is related in the form of possession, access, ownership and control while the term earth provides another dimension of the relationship between 
indigenous peoples and their environment (Gray, 2009). This is what we have referred to as tangible and intangible material good above. This idea of territory and land seeks to look at the prior rights of indigenous peoples over those of invaders or encroaching colonists. In the same line, Gray (2009) further emphasizes that the idea of possession is not the question when this is looked at from the concept of the earth when the territory acquires a connotation for indigenous peoples, which has spiritual and religious values. He adds, "the earth or the spirituality connected with their territories and lands is a sign of the specific bond and understanding between indigenous peoples, which ties them to the place where they live." Referring to the territorial rights, he provides an example from his fieldwork among the Amarakaeri in southern Peru, and concludes, "without recognition of territorial rights, indigenous peoples face alienation, dispossession and landlessness."

Keeping the above discussions in mind, the present work proposes to look at the territorial rights of the Mapuche with an interdisciplinary approach. In the first part, the present study focuses on developing the conceptual framework of Mapuche cosmovision of land and territory. In the second part, the paper follows a brief analysis of the historical context of the territorial conflict between the Chilean State and the Mapuche people. In the third section of the work, the various national and international regulatory framework along with their limitations to resolve this territorial conflict has been discussed. Finally, the paper tries to synthesize and talks about integrating the Mapuche land cosmovision in the socio-political discourse and be considered while formulating any land policy involving Mapuche and other indigenous peoples inhabiting in Chile in future. The discussions and analysis have been carried out through a comprehensive literature review and integrate an interdisciplinary approach to look at this issue, both from the philosophical perspective and from the socio-political policy framework of government. The land acquires an intangible form in the viewpoint of the Mapuche and all indigenous peoples with deeply rooted traditions and customs in them and this fact needs to be considered while discussing the territorial problem.

\section{Land and Territory: Focus of the Mapuche cosmovision}

It is a known fact that native peoples have unique connectivity with the various elements of nature, such as wind, water, land, the sun, among others. The word Mapuche means "people of the land", and that land does not only refer to space through which one walks or travels in a tangible way, but it also constitutes a set of dimensions, energies and types of lives, which together would signify land for Mapuche.

Likewise, and in general terms, it is explained that the cosmogonic space or the space of the universe and the Earth in Mapuche cosmovision is divided according to the characteristics and elements that make them up (Fig. 2). In this context, Vidal et al. (2017, p. 111) indicate that there are "two spaces above" (wenü mapu, 'land of above' and anka mapu, 'midheaven') and "two spaces below" (naq mapu, 'land inhabited by living beings' and miñce mapu, 'land below'). For Nanculef (2016, p. 109), the territorial description is simple and easy but with a deep feeling "in such a way that when we speak of wenü Mapu, it literally means the lands of above; naq Mapu, the lands here, of this planet where we live as humans, where we share with nature and where the $a z M a p u$ is. Therefore, the naq mapu would be the place where people, animals and plants and the az mapu (characteristics of a place) relate to each other, corresponding to the different newen (force) and gene (energy that possesses a space) that inhabit the waj mapu. Nanculef (2016) asserts that the Minche Mapu are the underground lands or of an unknown cosmic dimension. 
The concept of the waj mapu emerges strongly, which is identified as the territory that the Mapuche have inhabited from the beginning, and each territory of the waj mapu, in turn, is identified and recognized with the meli wixan mapu, which is composed of the following mapu (Fig. 2):

- $\quad$ pikun mapu (land of the north);

- wiji mapu (land of the south);

- $\quad$ puel mapu (land of the mountains);

- lafquen mapu (land of the sea)

Each of these subdivisions has its own identity. For example, in the lafquen mapu, mention is made of the sea and the energies that live there, which includes the life of the ancestors and the various gen; the puel mapu, refers to the mountains, to the volcanoes, where it is possible to find the ancestral spirits, those known as pillan.

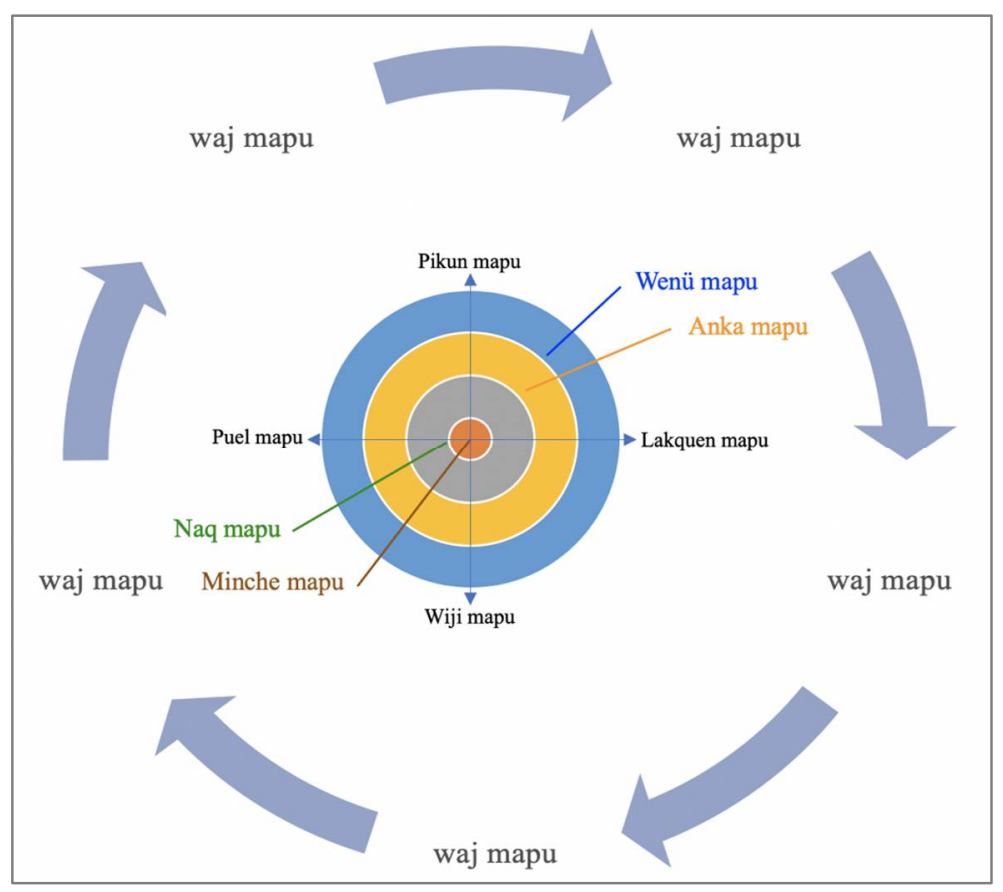

Figure 2: Representation of waj mapu (Own elaboration)

In the context of the waj mapu, there is another concept referring to the wallontu mapu, which is associated with the wenü mapu. Nanculef (2016, p. 109) mentions, "the Wenü Mapu is another land like this (waj mapu), submerged in the fourth or another dimension, where only the great kimche, the great machis and the great knowledgeable of the Mapuche People have been taken to." Hence, the wenü mapu can be understood as a place where not all the people who have died can go. Rather, it is a place that corresponds to the Mapuche people with küme zugu ka küme kimün, being reserved for the Mapuche who progress, advance and provide help to others, regardless of the social role that the person develop within the community or lof che.

The relationship that the Mapuche has with the territory is very complex to be understood in a rational way since it works in different dimensions. As has been proposed, there is respect between the Mapuche being, the wallontu mapu and the wenü mapu, as well as, a tangible and intangible relationship with the naq mapu when living together with other living beings, whether 
natural, spiritual or energetic. At the same time in the minche mapu inhabit those gen and newen who take care of the earth's natural resources, such as minerals and underground water. Therefore, when the Mapuche speaks of territory, s/he speaks of a whole, of a general composition relevant to human and non-human life, hence, the link that s/he develops with the waj mapu and the wallontu mapu comes from even before s/he was born in the naq mapu.

Therefore, for being Mapuche it is necessary for each person to know and recognize their territory because the az mapu of that place is also in part of their mulfün (blood). That is why, when a Mapuche presents himself or herself, s/he indicates her/his kupan (lineage) and tuwün (territory). Tuwün is not only part of the Mapuche person individually but also of every living being that resides in a given territory.

The kinship relationships within the Mapuche families are directly linked to their territory of origin since the surnames grant belonging and characterize people with different places and compositions of the meli wixan mapu. Among these are animals, birds, reptiles, natural phenomena and inanimate elements of nature such as cheuque (ostrich) nahuél (tiger); huenu (sky); antü (sun), cura (stone); wenü (sky); co (water); lemu (mountain) among others (Latcham, 1909). Besides, an old concept rarely mentioned is of the küga, "which grants identity and belonging and, therefore, the family history and its territory" (Galdames, 2009). Moreover, the küga provides a symbolic relationship with the elements of the natural space. On the other hand, Duran and Catriquir (1996) explain that the küga corresponds to a family trunk, in which the people who make up the family group identify certain elements, such as nature, spiritual strength and the history of the küga. Furthermore, they share a determining territory, the same leadership and react to cultural and symbolic issues typical of the küga nomenclature.

Hence, for the Mapuche culture, the history of their family group or parental trunk is relevant because to carry and know the history of their ancestors is to have kupan, likewise, the tuwün grants belonging and territorial identification of the che in the waj mapu (Vidal et al. 2017). Therefore, knowing their respective kupan and tuwün allows them to have a logical and empirical explanation of their family and community, to understand the socio-cultural aspects of the community in past, present and future time (Quintriqueo \& Quilaqueo, 2006). It is convenient to underline that tuwün is associated with the maternal territorial inheritance, although it also "refers to the knowledge of kinship networks, which are linked to the content of territorial and parental origin. This has been historically constructed and taught to boys, girls and young people through "social memory" (Quilaqueo et al. 2011).

On the other hand, another important concept to mention and explain is the Gijañmawün, which expresses the action of giving and receiving and receiving and giving (exchange), a relevant cultural activity within the Mapuche culture. The gijañmawün is not only related to human beings, but also to the genes and newen that make up the waj or wallontu mapu. That is why, "through the different manifestations of Gijañmawün, the che makes it possible to link all the manifestations of life, present in the territory where it lives" (Report of the Historical Truth and New Deal Commission, 2003).

That is why, for the Mapuche being, the territory is so relevant, since it does not only involve a material space where people live or plant but also considers sacred space that must be respected by the gijañmawün. For example in a gijatuwe (natural ceremonial space), the principle of reciprocity is generated through gijañmawün where nature, the sun, the moon, the wind and the water deliver their energies to the people who participate in the gijatuwe. Likewise, the people receive the energies and offer their food, such as toasted flour, bread, vegetables and their gijatu 
(Mapuche prayer), with the purpose of giving and receiving in a context of unification between the human being, nature, the ancestors and the genes of the Mapuche world.

As a synthesis, the connectivity between the Mapuche being and the land transcends spaces, since the Mapuche defines himself as a man of the land (Mapu/terre, che/gente). Therefore, the value of the land in the Mapuche culture has neither borders nor socio-political explanations, since the ancestral philosophy that sustains the culture is framed in their own conceptions, beliefs, knowledge, which form a way of life, typical of the original Mapuche people. Therefore, one could understand and mention that the land for the Mapuche would configure a celestial, earthly and intraterrestrial space, with material and eternal elements present in nature. This, when considered, valued and activated in daily life, would allow triggering the natural balance of the different energy sources (physical, mental and spiritual) in the context of the anka mapu or ragin mapu, place where earthly life is developed.

\section{Historical context of territorial conflict between the Chilean State and the Mapuche}

In this section, the paper has provided a brief historical context to understand the genesis of the territorial problem of Mapuche. The conflict over the ancestral territory of the Mapuche has its origin in the mid-19th century, after the independence of Chile in 1818. One of the main tasks of the Chilean State consisted of the marking the territory geographically limiting to the Biobío River ( $36^{\circ} \mathrm{S}$; González \& Bernedo, 2013). The expansion of the territory in southern Chile, between the Biobío River and the Reloncaví Estuary, was marked by the arrival of European immigrants to the province of Llanquihue (since $\sim 1850$ ), the occupation of Araucanía and the intensification of both, the State presence and Chilean and European settlers (Flores, 2019).

As per the 1833 Constitution, the Chilean state declares itself unique and indivisible, limiting and extending its domains and perpetuating political-legal sovereignty over Mapuche ancestral lands (Mariman, 2009; Crow, 2013; Royo, 2015). Additionally, the ancestral communities were subordinated both politically and culturally under the new Magna Carta, reinforcing the situation of poverty and marginality established since the Spanish colonial system. In the Constitution of 1833, it was declared that

The territory of Chile extends from the Atacama desert to Cape Horn and from the Andes mountain range to the Pacific Sea, including the Chiloé Archipelago, all the adjacent islands and that of Juan Fernández.

As of $\sim 1850$, the Chilean State began occupying the indigenous territory through the irregular use of legal instruments (like contracts of sale, lease or assignment). These instruments facilitated the usurpation of ancestral territories, which were unknown to the indigenous community (Aylwin, 2002; Almoacid, 2009). Subsequently, these legal instruments were legitimized through decrees and laws that granted collective land titles (titles of mercy) to the Mapuche community (Aylwin, 2002; Bengoa, 2017; Gazmuri, 2018). However, these property rights corresponded only to the "effectively occupied territory", while the remaining territory was declared as property of the Chilean State (Almoacid, 2009; Royo, 2020; Huenchimul, 2020a). Additionally, the Chilean State used various administrative-legal tools, such as the creation of the new Arauco Province (under Law 02 July 1852) that allowed the Chilean jurisdiction to be strengthened and legitimize the usurpation of the recently annexed territories (González \& Bernedo, 2013).

In 186o, Army Colonel Cornelio Saavedra was appointed Mayor of the Province of Arauco and was responsible for initiating the military invasion of the Ngülümapu (Mapuche territory 
having geographical space from the Bio-Bio River to the south and which is currently under Chilean administration; Rebolledo, 2017). This violated the Treaties of Quilín (signed in 1641 between the Mapuches and the Spanish Crown) and Tapihue (signed between the Chilean State and Mapuches in 1825), where Mapuche sovereignty was recognized from the Bio- Bio towards the south (Andreucci, 1998; Aylwin, 2002; Huenchumil, 2020a). His plan of "pacification or conquest" consisted of the construction of defensive lines formed by a series of military forts (Forts Collipulli in 1867; Cañete in 1868; Purén and Lumaco in 1869) and the sale of land to the non-Mapuche population to increase the population density of national and foreign settlers in the area, facilitating the complete occupation of the region (González \& Bernedo, 2013; Bengoa, 2011; de la Harpe, 2019).

Additionally, the State promulgated a law (December 4, 1866) that allowed the establishment of populations in indigenous territories, especially on land which was the property of the State and those which was about to be acquired (Almonacid, 2009). On the other hand, in Araucanía this same law prevented the alienation of land between individuals, except for those who were enrolled and registered, and thus began the delivery of titles of mercy in the name of the republic (Almonacid, 2009; Flores, 2019; Fig. 3). The aim was to "reduce" the large surface area of land that was in the hands of the Mapuche and make available the physical space for the establishment of Chilean and foreign settlers (Aylwin, 2002; Almonacid, 2009; Flores, 2019).
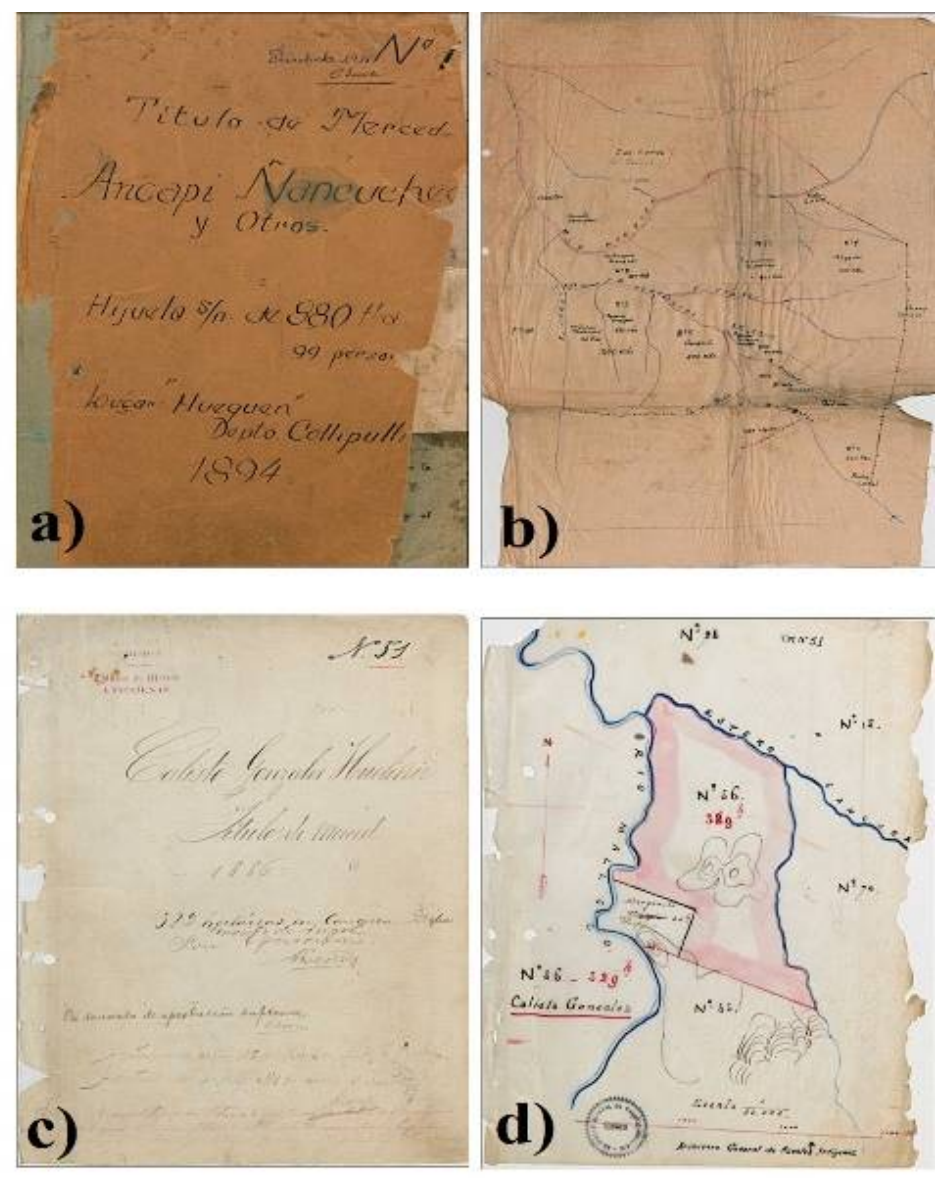

Figure 3: Mercy titles granted by the Chilean State to the Mapuche community to legally establish dominion over the portion of land occupied. a) \& b) Title of Mercy $\mathrm{N}^{\circ} 1$ granted in 1894 to Ancapi Nancucheo and others. c) \& d) Title of Mercy $\mathrm{N}^{\circ} 51$ granted in 1886 to Calisto Gonzalez Hueliñir. Source: CONADI General Archive of Indigenous Affairs (2020). 
Between 1861 and 1883 the Mapuche territory was politically incorporated into the Chilean State, a situation that marked the beginning of a "Creole colonization" through the settlement in the southern regions recently incorporated into the country. This colonization, in addition to promoting the appropriation and exploitation of the natural resources of the Mapuche territory, aimed at turning the Mapuche into a minority ethnic population or assimilating them into a regional multi-ethnic population (de la Maza \& Mariman, 2012).

For approximately 22 years (1861-1883), the implementation of the pacification plan imposed by Chile and initially directed by Saavedra meant the reduction of $\sim 10$ million hectares to $\sim 500$ thousand hectares of ancestral territory (González, 1986; Huenchumil, 2020b). Besides, it signified the dispossession of a central element of their culture and main source of livelihood, since agriculture was historically the axis of the Mapuche economy (Aylwin, 2002; Andrade, 2019). Additionally, the arrival of foreign settlers brought with them customs and idiosyncrasies, beliefs and religions that strongly affected the Mapuche culture (Bengoa, 2017).

At the end of the $19^{\text {th }}$ century and beginning $20^{\text {th }}$ century (between $\sim 1883$ and $\sim 1930$ ), the Chilean State, through its "Ministry of Immigration and Colonization" and the "Settlement Process", began the appropriation of land to the fiscal domain and granted land concessions to Lonkos and its communities especially between the Biobío and Toltén rivers (Bengoa, 2017; Gazmuri, 2018; Flores 2019). Only during the period 1883 - 1930, the State granted about 3,00o titles of Mercy in the provinces of Arauco and Osorno, leaving practically all the rest of the territory under state ownership (Miguez, 2013), formalizing in some way the usurpation of ancestral territories. In order to strengthen control over the indigenous territories of the border area of Arauco, in 1887 two provinces were created (Cautín and Malleco) to end the special regime to which the old Mapuche lands were subject, and thus bringing them under the same regulations as the rest of the national territory (de la Harpe, 2019; Flores, 2019).

Starting in $~ 1920$, with the conclusion of the "settlement policy", the Chilean State promoted the division of Mapuche lands into "individually owned property" and also transferred lands to the non-indigenous population who used them for agricultural production (Aylwin, 2002). According to Almonacid (2009), the buying and selling of land were very active during that time. In the notary of the city of Valdivia, between 1788 and 1870 only 344 land titles were registered, while between 1870 and 1907 there were more than 7,00o thousand, of which indigenous people granted about 1,ooo. On the other hand, between 1931 and 1971, 832 reductions ${ }^{3}$ were divided out of the almost 3,000 existing ones, which meant the alienation of close to $\sim 100$,ooo hectares of Mapuche lands to non-indigenous populations during this period (Aylwin, 2002).

Beginning 1970, the government of Salvador Allende (Popular Unity government) used the New Agrarian Reform enacted in 1967 to increase the restitution of Mapuche lands through expropriation (Agrarian Reform Law No. 16,640; Andrade, 2019). Besides, with the promulgation of Indigenous Law No. 17,729 (promulgated in 1972), it was intended to guarantee the possession of Mapuche land through its immunity from seizure, to prohibit the sale to non-indigenous or legal persons and established the "undivided indigenous community" (which corresponds to the agreement of all members of the community to request its division; Andrade, 2019). In this period (1970 - mid-1973), in an unusual act, the State created a specific legal framework to restore the usurped lands to the indigenous peoples, a situation that allowed the recovery of $\sim 132,115.78$ hectares of territory by the Mapuche community, which included lands with Mercy titles and ancestral territories (Andrade 2019). However, this process of recovery of lands usurped by the State was interrupted because of the coup d'état that occurred in September 1973, where the process of territorial restitution was stopped and the policy of usurping started again (Aylwin 2002; Andrade, 
2019). Given the fact that during the expropriation of lands that occurred between 1970 and 1973, a large part of the lands was not titled in the name of the beneficiaries under the land reform, it was subsequently privatized through a process of regularization of ownership known as "counteragrarian reform" (Aylwin, 2002). This counter-reform, added to the promulgation of Decree-Law 2568 (1978), restored and rooted individual private property. The community property recognized in the titles of Mercy was eliminated and the partial and/or total return of the expropriated properties to its former owners and the sale of lands with forest industry qualities began (Aylwin 2002; Andrade, 2019). According to Molina (2000), about 415,053 hectares of land were transferred to the National Forestry Corporation, of which an important part was auctioned at very low prices to forestry companies.

During Pinochet's dictatorship (1973-1989), the Chilean State visualized that indigenous territory could drive the region's economic development through the exploitation of natural resources, given the extraordinary soil quality for agricultural and forestry production. The territory, therefore, began to be considered as an object of commercialization (Haughney, 2007), ignoring the meaning and context of the territory under the indigenous peoples' cosmovision. Furthermore, the State promoted a policy of division and reduction of indigenous lands to end the concept of collective possession of territory and the special status that indigenous people and their lands had, integrating them into the same regime of national law to which all Chileans were subjected (Aylwin, 2002). The creation of these "individual smallholdings" had a strong impact on the impoverishment of the rural Mapuche population, a situation that accelerated the massive exodus of indigenous people to urban centres (Aylwin, 2002).

During 1985 - 1990, various actors from the indigenous community raised proposals and demands aimed at protecting their fundamental rights "as ancestral peoples" (especially the land rights not recognized in the current Chilean constitution) and the establishment of a new relationship with the State (Aylwin, 2002). After 1990, in Chile, the Indigenous Law (Law No. 19,253) was promulgated and the complex process of ratification began with the Convention No. 169 of the International Labour Organization (1989), which was signed only in 2008. Although during the last 30 years (1990-2020) the Chilean State has advanced in the establishment of political and administrative measures to favour various aspects of ancestral communities, these have not yet solved the problem of usurpation and recovery of ancestral territory. In the next section, the study examines the national and international frameworks, which have been developed to tackle and solve the problem of indigenous territorial rights.

\section{National and international regulatory framework and its limitations for resolving conflict over territory}

\section{Chilean Indigenous Law}

The Chilean Indigenous Law (Law No. 19,253) was promoted by the native peoples to establish and consecrate the constitutional recognition of their existence. Enacted in 1993, it laid the foundations for the new socio-political relationship between the Chilean state and the native peoples (Boccara and Boccara, 1999). In terms of the land, the Indigenous Chilean law recognizes the importance of land for the indigenous community. The very first paragraph of the $1^{\circ}$ Article of Indigenous Law № 19,252 (1993) emphasizes that:

The State recognizes that the indigenous people of Chile are the descendants of the human groups that have existed in the national territory since pre-Columbian times, which 
preserve their own ethnic and cultural manifestations, the land being for them the main foundation of their existence and culture (Indigenous Law, 1993) ${ }^{4}$.

On the other hand, the Indigenous Law No. 12,253 (1993) in Title II of the recognition, protection and development of indigenous lands in Chile, states that indigenous lands are those that have been ancestrally occupied by indigenous peoples, with Mercy titles, grant titles, free cessions and other forms that the State has used to cede, regularize, deliver or assign lands to indigenous people. Furthermore, Article 13 indicates that lands shall enjoy the protection of this law and may not be alienated, embargoed, taxed, or acquired by prescription, except between indigenous communities or individuals of the same ethnic group.

Although the promulgation of this law recognizes and values cultural diversity, it creates a new institutional framework in charge of indigenous peoples' affairs (National Corporation for Indigenous Development, CONADI) and implements some intercultural policies in education and health sector; it has become clear that these have not met indigenous demands (Boccara and Boccara, 1999; Levil 2006). This is because the normative framework established in the indigenous law has not been able to capture the complexity of the indigenous reality, in terms of internal sociocultural diversity, lack of intermediaries according to the new institutional framework of interrelations, the importance of the urban indigenous population, among other aspects (Boccara and Boccara, 1999).

\section{Convention 169 of the International Labour Organization (ILO)}

International Labour Organization Convention 169 about Indigenous and Tribal Peoples in Independent Countries was adopted in Geneva on 17 June 1989 by the International Labour Conference (Aguas \& Nahuelpan, 2019) and is a binding legal instrument on the rights of indigenous peoples (Courtis, 2009). In Chile, although the process of discussing the treaty began in 1991, it was only ratified in 2008 during Michelle Bachelet's first term. The coming into force of this Convention generated high expectations regarding the possibility of opening up new spaces for political relations between the State and indigenous peoples. This was particularly true of the requirements that the State had to impose on itself in order to adapt its legislation to the content of the Convention and to promote changes that were consistent with the minimum standards for the application of the Convention and that satisfied the expectations of indigenous peoples (Aguas \& Nahuelpan, 2019). However, despite the advances in recognition policies that have been promoted since 2008, the socio-political context of the approval and subsequent ratification of ILO Convention 169 in Chile did not improve the tense and conflictive relationship between the State and the indigenous peoples that has been observed to date (Correa \& Mella, 2010; Aguas \& Nahuelpan, 2019).

Articles 13-16 of ILO Convention 169 recognize the rights to land and territory. These articles recognize the special importance of land and territories for the cultures and spiritual values of indigenous peoples; recognize property and possession rights over the lands they traditionally occupy; recognize the right of indigenous peoples to participate in the use, management and conservation of the natural resources pertaining to their lands. Another important aspect is that the Convention extends the concept of lands to the territory "which covers the whole of the habitat of the regions, which the peoples concerned, occupy or use in some or the other way" (Aylwin, 2012). 


\section{Limitations and/or gaps in the regulatory framework and the role of the Chilean state in resolving the territorial conflict}

Although the promulgation of the Indigenous Law and the creation of CONADI materialized rapidly in 1993 (Law No. 19253), the approval of Convention 169 did not happen fast and was approved in 2008. Even though in the genesis of the draft law, indigenous representatives participated actively in the creation of Special Commission on Indigenous Peoples (CEPI) in 1990, the final version approved by the Congress underwent significant modifications that largely detracted from its meaning (Vergara et al., 2004). Among the modifications to the original text is the replacement of the notion of "native peoples" by "ethnic groups or indigenous communities", given that the first concept (native peoples) can imply aspects that go beyond the simple assignment of rights and legal guarantees (i.e. identity, autonomy, dominion over territory; Ponte, 2004; Gaete, 2012). In other words, the categorization of native peoples as "ethnic groups" makes it clear that political rights are not recognized and the problems associated with the domination of territory are not resolved either (Simon \& Parra, 2014).

This law establishes some mechanisms that allow the recovery of usurped lands through the purchase by the State, which are then transferred to the indigenous communities. However, the purpose of this recovery is to achieve an economic-productive objective where indigenous communities use the land for agricultural production and to increase income for economic prosperity, and not as a reparation measure enshrining the return of the usurped lands (Chauca, 2006).

While the conflict between the Chilean State and the indigenous communities, especially the Mapuche, is centred on the recovery of land, there are other aspects in dispute that are closely linked to the territory, such as demands for water, recognition of cultural and linguistic rights, marginality and poverty with respect to the rest of Chileans (Chauca, 2006; Richards \& Gardner, 2013). Although these aspects are partially covered in the indigenous law, they are still insufficient to resolve the demands of the indigenous peoples in matters of sovereignty, lands, and the natural resources present in the disputed territories (Aylwin, 2002; Chauca, 2006; Orellana, 2015). Thus, today, indigenous law does not prohibit the expropriation of lands of indigenous communities because of a need by the State.

There are many examples of such case like the case of the Ralco hydroelectric plant in southern Chile causing permutation of lands (or rather a "disguised expropriation") and thus, flagrantly violated the national Indigenous Law and international provisions related to the rights of indigenous peoples, destroying ancestral lands, cemeteries and other resources of the natural and cultural heritage of the Mapuche people (Larraín, 2006; Klein, 2008; Carruthers \& Rodriguez, 2009; Astorga et al, 2017; Schmidt \& Rose, 2017; Hale \& Millaman, 2018). Although CONADI in its initial days played an important role in the struggle for the establishment and fulfilment of indigenous rights enshrined in the Indigenous Law, it's strong opposition to the land swap negotiated by the construction of the Ralco hydroelectric plant in the Upper Bio-Bio sector triggered the dismissal of CONADI's director, strongly affecting its position as a "mediating body" between the State and indigenous peoples (Aylwin et al., 2015; Reyes, 2018).

The Chilean government prioritized the national electricity law and the interests of the company involved (Endesa Spain), within the framework of an energy policy that also lacked elements of environmental, social and political sustainability. The above is not an isolated case, since political operators, mandated by the governments in power, use public agencies to favour certain economic areas (i.e. energy) to the disadvantage of local communities, including indigenous 
communities (Molina \& Correa, 1998; Urquieta, 2013). This shows that even though the significance of the land has been equated with the existence and cultural values of the indigenous life, the same has not been transferred at a more practical level. The above instances where land has been grabbed from them on the account of neoliberal modernist policies, demonstrate it.

On the other hand, ILO Convention 169 recognizes the "multidimensionality of land" (i.e. tangible and intangible land). This means that the land is not only space used by the titleholder but also recognizes all the lands to which they have had access traditionally. In addition, the concept of "territory" is incorporated as part of "lands", the definition of which covers the totality of the habitat of the regions that the peoples concerned occupy or use in some way or another, with political rights and self-determination being considered and recognized (i.e. self-administration by the people without pressure from the State).

For the Chilean State, ILO Convention 169 has become an instance where the indigenous peoples must be consulted in any situation that affects their development and work within the lands they belong to. However, this right to consultation is not binding, so the effectiveness of the indigenous voice acquires only a consultative character and is not necessarily considered in the development of administrative and political measures (or other types) that affect the work of the community.

Recently, the Chilean State (Government of Chile, 2018) launched the "Plan Impulsa Araucanía 2018-2026" that seeks

The vast majority of the Mapuche people have integrated themselves into the Chilean reality, learning and managing their linguistic, cultural and religious codes, which does not imply that they have abandoned their cosmovision. In recent years, and as a result of multiple factors such as the greater openness of Chilean society to diversity, access to experiences from other latitudes, and the relevance that the international community has given to the rights of indigenous peoples, a climate of greater recognition and more propitious for effective and genuine intercultural dialogue has been generated (National Agreement for Development and Peace in Araucania, p. 3) $)^{5}$.

However, one of the first questions that we can designate corresponds to the fact that the integration of the indigenous peoples and especially the Mapuche communities to the "Chilean reality" occurs by the imposition of the State more than by a voluntary matter. Historically, it has been evident that the Chilean State has carried out various indoctrination campaigns to "homogenize the culture, behaviour, religion, among other aspects" treating all the inhabitants as "one single nation" and ignoring (although legally not indicated) the plurinationality of the residents of this portion of land called Chile. In other words, some indigenous communities (i.e. Mapuche and Rapa-Nui) openly declare themselves as "non-Chileans". On the other hand, even though a series of measures are proposed to improve the mechanisms of access to and recovery of land by the Mapuche people, the neoliberal ideas regarding territory are maintained and reinforced. This can be perceived especially with regard to the reduction of the territory (i.e., the granting of individual rights that take precedence over collective rights), the commodification of land (i.e., the reduction or elimination of the prohibitions on buying and selling established in the current indigenous law), and the "economic" purpose of granting new land only for productive purposes.

Now, if one looks at the agricultural use of the land, it is also interesting to relate a historical evolution in which the use of the land is adapted, but always with a very Mapuche worldview spirit. Before the arrival of the Spaniards, the Mapuche economy was situated as proto-agrarian (Bengoa, 1996) based on hunting and gathering, but after the conquest, they introduced cattle, sheep and 
horses and became cattle breeders (Bengoa, 1996). However, by introducing these elements into their economy, they also integrated them into their worldview by giving them special values.

In the non-indigenous world vision, land corresponds to something material and delimited, which is associated with the conception of absolute private property, bids its unlimited exploitation to serve the economic interest. This conception fits into the neoliberal productive model because it integrates land as an element of the cycle of production of wealth. Consequently, actors such as the state and the market support this vision, seeking in this way the economic development of the country. Under this prism, everything is evaluated under criteria of economic profitability even if the latter can only be short term because the intensive exploitation of the land unbalances it so much that it does not produce more afterwards. The indigenous people privilege the community's use of the land, the distribution of the land according to need, the relationship of respect and harmony with the land, the sacredness of their bond with the land, and the property protected by an ancestral possession of the land and therefore by a rootedness that is historical (Osorio, 2017).

\section{Need to integrate the Mapuche land cosmovision in the socio-political discourse}

The indigenous peoples' cosmovision implies a deep emotional relationship with nature, where all the elements and components (physical, chemical and biological) of the environment are material and spiritual entities that provide life, health and harmony (Osorio, 2017). From an ecological point of view, the cosmovision of the land for any indigenous people can be conceived as a holistic approach that incorporates all the goods and ecosystem services (tangible/intangible) that the territory provides and allows the existence of all forms of life. From this perspective, the integration of the indigenous cosmovision would allow the reduction of environmental pressure on the territory, which has generally been considered as an "economic-productive object". Furthermore, it would make it possible to maintain the ecological balance (homeostasis) and the carrying capacity of the natural systems used by man (native and non-native) to ensure the existence of future generations.

On the other hand, from an economic perspective, the worldview of the territory would imply that there can and should be exploitation of all the natural resources that the land provides, but this should be rational. However, the contradiction between these two visions (indigenous cosmovision and non-indigenous world vision) appears when the purpose of this exploitation is oriented to the search and accumulation of wealth and not to the subsistence of the community that uses the territory. The land acquires a sacred and spiritual order in the indigenous cosmovision (Web, 2014; Osorio, 2017).

In 1994, the twenty-six experts of the UN Sub-Commission on the Prevention of Discrimination and the Protection of Minorities unanimously approved the Declaration, which declares in Article 26,

Indigenous peoples have the right to own, develop, control and use the lands and territories, including the total environment of the lands, air, waters, coastal seas, sea-ice, flora and fauna and other resources, which they have traditionally owned or otherwise occupied or used. This includes the right to the full recognition of their laws, traditions and customs, land-tenure systems and institutions for the development and management of resources, and the right to effective measures by States to prevent any interference with, alienation of or encroachment upon these rights. 
Article 43 of the United Nations Declaration on the Rights of Indigenous Peoples (UNDRIP) ${ }^{6}$ enshrines the rights that "constitute the minimum standards for the survival, dignity and well-being of the indigenous peoples of the world." The UNDRIP affirms that "all doctrines, policies and practices based on or advocating superiority of peoples or individuals on the basis of national origin or racial, religious, ethnic or cultural differences are racist, scientifically false, legally invalid, morally condemnable and socially unjust". In this context, the current Chilean indigenous policy seems to be inadequate and fail to recognize the socio-cultural and territorial rights of the Mapuche community. The socio-political measures imposed by the Chilean government till date to make their life "modern" boomeranged alienating them more from the Chilean society.

In light of the above background and discussions, emerges the discrepancy that could be the central focus of all disputes between the state and indigenous peoples. This discrepancy would be developed by the notion and vision that the non-indigenous world has about "development, modernity and growth" and which does not necessarily connect and represent the feeling of the indigenous cosmovision. This would be mainly due to the degree of physical, emotional and spiritual connection that indigenous communities have with nature, which is difficult for the nonindigenous society to understand. The adaptation of the ILO Convention to the Chilean reality, as well as the functioning of the Chilean Indigenous Law, has not effectively enabled the formulation of political strategies that could allow the indigenous culture and worldview to be understood and brought into proximity with the non-indigenous population. In other words, the State must oblige itself to "generate and promote political measures for and with the indigenous people". There is a need to ensure the effective participation of native peoples in all processes of citizen participation and consultation. Their inclusion would allow the development of government measures and policies agreed upon by all the actors of society, which, then, will be recognized and accepted as legitimate by all in society.

In the perspective of the territorial dispossession that the native peoples have suffered as a result of the domination policy of the Chilean State, the notion of territory as a "one-dimensional material" problem must be changed, since we must consider the multi-dimensionality of the Territory (social, spiritual dimension) as well as the political rights associated with the notion of land. Additionally, any legal and administrative framework that has interference on lands and territories should conceive "development, modernity and growth" not from the perspective of classic neo-liberal extractivism but as an opportunity to promote economic progress based on care for nature and with an important cultural identity (Namuncura, 2000).

\section{Conclusion}

The territorial conflict between the Chilean state and the Mapuche people is far from over because Chile still does not recognize that the Mapuche territories were annexed and usurped through violence and deception. In addition to that, the socio-political measures imposed by the Chilean government until now to make their life "modern" boomeranged alienating them further from society. The historical context briefly developed in this paper points to this fact, and in present times, the Mapuche demand to return the illegally occupied territories is being echoed and reflected in the clashes between the State and the Mapuches. The Chilean state has promoted some legal tools to resolve, in its broadest context, the way in which the state relates to and interacts with the original peoples of Chile. However, these policies have been insufficient, biased and poorly operational, since they do not include and consider the cosmovision in the generation, implementation and operation of any public policy that directly involves indigenous peoples. 
Economic development by the dominant groups has led to systematic violence in the communities, where Mapuche families, young people and children from the different territories of the Waj Mapu have been flooded with disagreements and territorial injustices. Over the years, violence in the Araucanía region (south of Chile) has undoubtedly become a powerful strategy that seeks to validate the neoliberal economic power in the ancestral Mapuche territories, leaving aside what Osorio says (2017, p. 185): "For the indigenous peoples, nature is mother, the earth is mother, and the elements of the natural environment that exist in the territory are material and spiritual entities that give life, health and harmony".

Therefore, it is proposed that the state visualizes the spirituality of the Mapuche people, where territorial rights are also understood as a force for balance between people and nature, where respect and harmony for the land prevails, strengthening indigenous autonomy and identity as part of the cultural differences of a plurinational state. The Mapuche people, like other indigenous peoples, believe in an economy of life and respect for the environment, encourage community and collaborative life among those close to them. Besides, they appreciate the value of land use and not the value of an economic exchange on a large scale as it has been developing from the state.

\section{Notes}

${ }^{1}$ Instituto Nacional de Estadísticas, Chile. (National Institute of Statistics)

${ }^{2}$ Rustic property that is generated by the distribution of physical space by the State

3 Portion of the small and delimited territory where Mapuches were forced to live in a completely artificial way and not according to their traditional form

${ }^{4}$ Own translation

5 Own translation

${ }^{6}$ adopted by the UN General Assembly in 2007

\section{References:}

Aguas, J., \& Nahuelpan, H. (2019). Los límites del reconocimiento indígena en Chile neoliberal. La implementación del Convenio 169 de la OIT desde la perspectiva de dirigentes Mapuche Williche. Cultura, Hombre y Sociedad, 29(1), 108 -130. https://doi.org/10.7770/o719-2789.2018.cuhso.04.ao1

Andrade, M. (2019). La lutte pour le territoire mapuche au Chili, une affaire de pauvreté et d'environnement. [The struggle for mapuche territory in Chile: an issue about poverty and environment]. L'Ordinaire des Amériques (On line), 225. https://doi.org/10.400o/orda.5132

Andreucci, R. (1998). La incorporación de las tierras de Arauco al Estado de Chile y la posición iusnaturalista de la revista católica. Revista de estudios Histórico-Jurídicos, 20, 37-84. https://doi.org/10.4067/So716-54551998000200002

Almoacid, F. (2009). El problema de la propiedad de la tierra en el sur de Chile (1850 - 1930). Historia, 42 (1), 5-56. https://doi.org/10.4067/So717-71942009000100001

Astorga, E., Carrillo, F., Folchi, M., García, M., Grez, B., McPhee, B., Sepúlveda, C., \& Stein, H. (2017). Evaluación de los conflictos socio-ambientales de proyectos de gran tamaño con foco en Agua y Energía para el periodo 1998 - 2015. Final Report. Consejo Nacional de Innovación para el Desarrollo (CNID). pp. 264. http://www.cnid.cl/portfolio-items/informe-evaluacion-de-los-conflictos-socio-ambientalesde-proyectos-de-gran-tamano-con-foco-en-agua-y-energia-para-el-periodo-1998-al-2015/

Aylwin, J. (2002). Políticas Públicas y pueblos indígenas: El caso de la política de tierras del Estado Chileno y el Pueblo Mapuche. Universidad de la Frontera. 
Aylwin, J. (2012). Los derechos de los pueblos indígenas sobre la tierra y el territorio en América Latina y el Convenio 169 de la OIT. In Aylwin, J., \& Tamburini (Eds.), Convenio 169 de la OIT. Los desafíos de su implementación en América Latina a 25 años de su aprobación (pp. 46-61). Grupo Internacional de trabajo sobre Asuntos Indígenas.

Aylwin, J., Fierman, E., Kausel, T, \& Lawrence, S. (2015). The future of hydropower in Chile. Journal of Energy \& Natural Resources Law, 32(4), 425-481.

Bengoa, J. (1996). Historia del Pueblo Mapuche Siglo XIX y XX. Santiago de Chile. Ediciones SUR, 3ª Edición. http://www.sitiosur.cl/r.php?id=124.

Bengoa, J. (2011). Los Mapuches: Historia, cultura y conflicto. Cahiers des Amperiques Latines. https://doi.org/10.400o/cal.118

Bengoa, J. (2017). Mapuche, colonos y el Estado Nacional. Editorial Catalonia.

Boccara, Guillaume, \& Ingrid Seguel-Boccara. (1999). Políticas indígenas En Chile (siglos XIX Y XX). De La asimilación Al Pluralismo (el Caso Mapuche). Revista De Indias, 59 (217),741-74. https://doi.org/10.3989/revindias.1999.i217.834

Carruthers, D., \& Rodríguez, P. (2009). Mapuche protest, Environmental conflicto and social movement linkage in Chile. Third World Quaterly, 30(4), 743-76o.

Chauca, J. (2006). Territorio, identidad y conflicto: la lucha por la tierra en la Araucanía chilena. Encuentro de Latinoamericanistas Españoles: Viejas y nuevas alianzas entre América Latina y España pp.1363-1376. halshs-00104263. https://halshs.archivesouvertes.fr/file/index/docid/104263/filename/J_CHAUCA.pdf

Constitución Política de Chile. (1833). Constitución de la República chilena, jurada y promulgada el 25 de mayo de 1833 .

https://www.bcn.cl/historiapolitica/constituciones/detalle_constitucion?handle=10221.1/17685

Crow, J. (2013). The Mapuche in modern Chile: A Cultural History. University Press of Florida.

Courtis, Ch. (2009). Apuntes sobre la aplicación del Convenio 169 de la OIT sobre pueblos indígenas por los tribunales de América Latina. Sur- Revista Internacional de Derechos Humanos, 6 (10), 53-81.

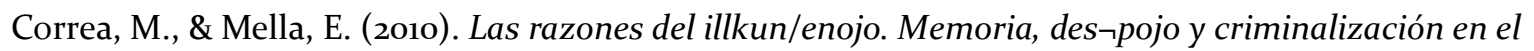
territorio mapuche de Malleco. Santiago de Chile. LOM Ediciones.

De la Harpe, C. (2019). ¿Qué explica la variación en las demandas en los conflictos étnicos?: El conflicto Mapuche-Estado en Chile [Unpublished Doctoral Thesis]. Instituto de Ciencia Política, Pontificia Universidad Católica de Chile.

De la Maza, F. \& Marimán, J. (2012). Los Mapuche del sur de Chile y sus relaciones interculturales. In Missana, S. (Ed.) Pueblos Originarios y sociedad nacional en Chile: La interculturalidad en las prácticas sociales (pp.126 - 150). Programa Conjunto Fortalecimiento de las Capacidades Nacionales de Prevención de Conflicto Intercultural. PNUD. Salesianos Impresores S.A. http://www.onu.cl/es/wpcontent/uploads/2013/10/Libro-Pueblos-Originarios-y-sociedad-nacional-en-Chile.pdf

Durán, T. \& Catriquir, D. (1996). Principios Educativos Mapunche. In Proceedings of the First Latin American Seminar on Bilingual Intercultural Education, edited by Academic Vice-Rector's Office. Temuco, Chile: Catholic University of Temuco.

Flores, J. (2019). La construcción del Estado chileno en la Araucanía a través de los papeles del Fondo de Intendencia de Cautín, 1887-1914. Bajo la Lupa, Research Sub-directorate, National Cultural Heritage Service. Accessed October 122020. https://www.archivonacional.gob.cl/616/articles-93552_archivo_o1.pdf

Gaete, L. (2012). El convenio $\mathrm{N}^{\circ} 169$. Un análisis de sus categorías problemáticas a la luza de su historia normativa. Revista Lus et Praxis. 2, 77-124. 
Galdames, O. S. (2009). Hugo Amigo y Patricia Bustos (editores) Apellidos mapuche: historia y significado. Cuadernos de Historia, 31, 173-178.

Gazmuri, J. (2018). La raíz del conflicto del pueblo mapuche y el Estado de Chile. El Mostrador, December 4. Accessed on 28 September 2020. https://www.elmostrador.cl/noticias/opinion/2018/12/o4/la-raiz-delconflicto-del-pueblo-mapuche-y-el-estado-de-chile/

Gray, A. (2009). Indigenous Peoples and Their Territories. In Adolfo de Oliveira (Ed.) Decolonising Indigenous Rights (pp.17-44). New York: Routledge.

Gobierno de Chile. (2018). Plan Estratégico Impulso Araucanía. https://planimpulso.cl/ Accessed on: 20 Octuber 2020.

González, H. (1986). Propiedad comunitaria o individual. Las leyes indígenas y el Pueblo Mapuche. Nütram № 3, año II. Santiago. Centro Ecuménico Diego de Medellín.

González, J., \& Bernedo, P. (2013). Cartografía de la transformación de un territorio: LA Araucanía 1852 1887. Revista de Geografía Norte Grande, 54, 179-198. https://doi.org/10.4067/So718-34022013000100010

Hale, Ch., \& Millaman, R. (2018). Privatization of the 'historic debt'? Mapuche territorial claims and the forest industry in southern Chile. Latin American and Caribbean Ethnic Studies. https://doi.org/10.108o/17442222.2018.1510658

Haughney, D. (2007). Neoliberal policies, logging companies, and Mapuche struggle for autonomy in Chile. Latin American and Caribbean Ethnic Studies, 2(2), 141-160.

Huenchumil, P. (2020a). Cómo la Constitución de 1833 trató de borrar la existencia del pueblo mapuche. Interferencia, September 18. Accessed on 30 September 2020. https://interferencia.cl/articulos/como-laconstitucion-de-1833-trato-de-borrar-la-existencia-del-pueblo-mapuche

Huenchumil, P. (202ob). Coronel Cornelio Saavedra en 1869: "Donde los indios se resisten es menester castigarlos. Interferencia, September 19. Accessed on 28 September 2020. https://interferencia.cl/articulos/coronel-cornelio-saavedra-en-1869-donde-los-indios-se-resisten-esmenester-castigarlos

Instituto Nacional de Estadísticas (INE). (2017). Síntesis de resultados CENSO 2017. https://www.censo2017.cl/descargas/home/sintesis-de-resultados-censo2017.pdf. Accessed on 10 October 2020.

International Labour Organization (ILO). (27 June 1989). Indigenous and Tribal Peoples Convention, C169. Available at: https://www.refworld.org/docid/3ddb6d514.html

Klein, F. (2008). The indigenous movements: The Mapuche case. Gazeta de Antropología, 24(1), Art. 4. https://digibug.ugr.es/handle/10481/7072

Larraín, S. (2006). El agua en Chile: entre los derechos humanos y las reglas del mercado. Polis Revista Latinoamericana 14. https://doi.org/10.32735/So718-6568/2006-N14-441 http://journals.openedition.org/polis/5091

Latcham, R. E. (1909). Antropología chilena. Revista del Museo de la Plata, 16 (1), 241-318.

Levil, X. (2006). Mapuche Urbano. Alcances acerca de la socialización y la interculturalidad a partir de una óptica educativa. Facultad de Educación y Humanidades, Universidad de la Frontera. Temuco, Chile.

Mariman, P. (2009). Guerra y ganado en la conquista del Ngulumapu (1860-1867). Espacio Regional, 2 (6), 35-59.

Miguez, R. (2013). Estado Chileno y Tierras mapuches: entre propiedades y territorialidad. In H. Olea (Ed.) Derecho y Pueblo Mapuche: Aportes para la discusión. Centro de Derechos Humanos. Universidad Diego Portales. Chile. 
Molina, R. (2000). Comunidades mapuche y empresas forestales: tierras, bosques y conflictos. In Pueblo mapuche, desarrollo y autogestión. Análisis y perspectivas en una sociedad pluricultural. Centro Integral de Desarrollo Comunitario Casa de la Mujer Mapuche. Sociedad Mapuche Longo Kilapan. Instituto de Estudios Indígenas UFRO. Temuco Chile: Ediciones Escaparate

Molina, R., \& Correa, M. (1998). Territorio y Comunidades pehuenches del Alto Bío-Bío. 2a edition. Corporación Nacional de Desarrollo Indígena (CONADI).

https://www.academia.edu/8745266/Territorios_y_Comunidades_Pehuenches_del_Alto_Bio_Bio_Ra\% C3\%BAl_Molina_y_Mart\%C3\%ADn_Correa_1998_

Namuncura, D. (2000). Los pueblos indígenas y los desafíos del 2000. Perspectivas, 3(2), 301-317.

Ñanculef, J. (2016). Tayiñ mapuche kimün. Epistemología mapuche-Sabiduría y conocimientos. Santiago: Universidad de Chile.

Orellana, M. (2015). Indigenous peoples, Energy and environmental justice: The Pangue/Ralco Hydroelectric Project in Chile's Alto BíoBío. Journal of Energy \& Natural Resources Law, 23(4), 511-528.

Osorio Calvo, C. A. (2017). Religiosidad e identidad: La lucha indígena como resistencia territorial desde la Espiritualidad. Revista Kavilando, 9(1), 184-203.

Ponte, M. (2004). Los pueblos indígenas ante el Derecho Internacional. Agenda Internacional, 20, 149 - 172.

Quintriqueo, S., \& Quilaqueo, D. (2006). Conocimiento de relación de parentesco como contenido educativo para escuelas situadas en comunidades mapuches de Chile. Cuadernos interculturales, 4 (7), 81-95.

Quilaqueo, D., Quintriqueo, S., \& San Martín, D. (2011). Contenido de aprendizajes educativos mapuches para el marco conceptual de un currículum escolar intercultural. Estudios pedagógicos (Valdivia), 37 (2), 233-248. https://doi.org/10.4067/So718-07052011000200014

Rebolledo, S. (2017). Nación Mapuche: Concepto, historia y desafíos presentes en Gulumapu-Araucanía. Cultura, Hombre y Sociedad (CUHSO), 27(1), 3-22.

Reyes, A. (2018). Mapuche communities and the politics of resistance. The case of Pilmaiquen - Chile. Working Paper Series 42. Ñuke Mapuförlaget. 55 pp. http://www.mapuche.info/wps_pdf/reyesNordstrom180330.pdf

Richards, P., \& Gardner, J. (2013). Still seeking recognition: Mapuche demands, state violence, and discrimination in democratic Chile. Latin American and Caribbean Ethnic Studies. https://doi.org/10.108o/17442222.2013.779063

Report of the Historical Truth and New Deal Commission [Informe de la Comisión de Verdad Histórica y Nuevo Trato]. (2003). Report of the Historical Truth and New Deal Commission, 3 (2): First part of the final report of the Mapuche Autonomous Work Commission. http://www.memoriachilena.gob.cl/602/articles-122901_recurso_7·pdf

Royo, M. (2015). Derecho Penal e interculturalidad como manifestación del principio de igualdad. Política Criminal, 10(19), 362-389. https://doi.org/10.4067/So718-33992015000100012

Royo, M. (2020). Libertad religiosa y pluralismo cultural: nuevos desafíos del derecho penitenciario. Política Criminalística, 15(29), 259 - 289. https://scielo.conicyt.cl/pdf/politcrim/v15n29/o718-3399-politcrim-1529-259.pdf

Schmidt, C., \& Rose, J. (2017). Environmental and cultural changes under Chilean neoliberalism: an ethnography of forestry and the Mapuche in Valle Elicura. Local Environment, 22(1), 2-16.

Simon, J. \& Parra, C. (2014). International Norms and national indigenous politics: MApuche demands for Territory in Chile. Nationalism and Ethnic Politics, 2o(1), 78-98. 
Urquieta, C. (2013). La deuda del Estado y Endesa con los pehuenches de Ralco. El Mostrador (online version). Accessed on 25 October 2020. https://www.elmostrador.cl/noticias/pais/2013/12/30/la-deudadel-estado-y-endesa-con-los-pehuenches-de-ralco/

Vergara, J., Foerster, R., \& Gundermann, H. (2004). Legalidad y Legitimidad. CONADI, Ley Indígena y Pueblo Mapuche. V Congreso Chileno de Antropología. Colegio de Antropólogos de Chile. A. G. San Felipe (Chile). https://www.aacademica.org/v.congreso.chileno.de.antropologia/149.pdf.

Vidal, E., Calfuqueo, J., \& Ancan, F. (2017). Espacio y tiempo en la construcción de la dimensión de aprendizaje rakizuam ka mapuzugun, a partir del saber de algunos kimce del bafkeh mapu. In G. Llanquinao \& R. Becerra (Eds.) Mapun kimün: Relaciones mapunche entre persona, tiempo y espacio (pp.97-117). Santiago: Ocho Libros.

Webb, A. (2014). Articulating the Mapu: Land as a form of everyday ethnicity among Mapuche Youth of Chile. Latin American and Caribbean Ethnic Studies, 9(3), 222-246.

\section{Annexure}

\section{GLOSSARY MAPUDUNGUN-SPANISH-ENGLISH}

Antü: sol- sun

Anka mapu o ragin mapu: lugar donde se desarrolla la vida terrenal - place where earthly life unfolds

Anka wenu: medio cielo- half sky/heaven

Az Mapu: características propias de un lugar- characteristics of a place

Cura o kura: piedra- stone

Che: persona - person

Co o ko: agua- water

Cheuque o choique: avestruz- ostrich

Gen: dueño o protector de la naturaleza (algo espiritual)- owner or protector

Gijañmawün: dar y recibir; recibir y dar, acción de reciprocidad- give and receive; receive and give, reciprocal action

Gijatuwe: espacio natural ceremonial- natural ceremonial space

Kimche: persona sabia- wise person/ person with knowledge

Küga: identidad y pertenencia familiar y territorial- family and territorial identity and belonging

Kupan: linaje- lineage

Küme zugu: buenas palabras expresadas con elocuencia y precisión- good words expressed eloquently and accurately

Küme kimün: buenos y virtusos conocimientos- good and virtuous knowledge

Lafquen mapu: tierra del mar- land of the sea

Lemu: monte- mountain

Lof che: comunidad territorial compuesta por familias mapuche- territorial community composed of mapuche families

Lonko: autoridad ancestral por linaje y reconocida por su comunidad para orientar, dirigir, y ayudar a su comunidad- ancestral authority by lineage and recognized by their community to guide, direct, and help their community 
Machi: persona con la capacidad de sanar fisica, psicológica y espiritualmente a una persona enferma- person with the ability to heal physically, psychologically and spiritually a sick person.

Meli wixan mapu: división de los espacios territoriales- division of territorial spaces

Miñce mapu: tierra de abajo- land below

Mulfün: sangre- blood

Nahuél: tigre- tiger

Nag/q Mapu: tierra que se habitan los seres vivos- land inhabited by living beings

Newen: múltiples tipos de fuerza- multiple types of force

Pillan: espíritu protector ancestral- ancestral protective spirit

Pikun mapu: tierra del norte- land of the north

Puel mapu: tierra de la cordillera- land of the cordillera/mountain range

Tuwün: herencia intangible del territorio ancestral- intangible inheritance of ancestral territory

Waj mapu: extensión amplia del territorio- wide extension of the territory

Wenü mapu: tierra de arriba- land of above/land above

Wiji mapu: tierra del sur- land of the south

Wallontu mapu: elementos del universo- elements of the universe

Wenü o huenu: cielo- sky

Dr Ranjeeva Ranjan is Assistant Professor in the Faculty of Education, Universidad Católica del Maule, Talca, Chile.

Dr Alexis Castillo is Researcher in Centro de Investigación y Estudios Avanzados del Maule (CIEAM), Universidad Católica del Maule, Talca, Chile.

Dr Karla Morales is Assistant Professor in Centro de Investigación y Estudios Avanzados del Maule (CIEAM), Universidad Católica del Maule, Talca, Chile. 